ISSN 2073-1558 online version: http://epub.oeaw.ac.at/eco.mont

\title{
Freshwater biodiversity under warming pressure in the Alps: a methodological framework for prioritization of restoration areas for small waterbodies
}

\author{
Beat Oertli, Christiane Ilg, Sandrine Angélibert, Janine Bolliger, Julien Crovadore, Eliane Demierre, Claire Julliand, \\ Andréa Finger-Stich, Christel Forré, Pierre-André Frossard, François Lefort, Mathieu Mayencourt, Umberto Piantini \\ \& Sergio Schmid
}

Keywords: pond and lakes, biodiversity, global changes, boreo-alpine species, landscape genetic, connectivity, social acceptance, freshwater restoration

\section{Abstract}

Freshwater biodiversity has shown to be highly vulnerable to climate warming. Boreo-alpine species are especially at risk in the Alps because they have to migrate to higher elevations to avoid local extinction. Effects of climate warming could be partly counteracted by creating new freshwater habitats: this would boost the population sizes of the endangered species and would increase the connectivity between Alpine waterbodies to facilitate the species' upward dispersal and colonization of new habitats. Nevertheless, the localization of new habitats has to be carefully chosen, as successful restoration (or habitat creation) depends on many abiotic and ecological variables (e.g. habitats density and quality, connection between bodies of water, presence of targeted species, resistance of landscape to species movements). Furthermore, various socioeconomic drivers and actors determine the land and water uses in the Alps. Therefore we developed an innovative method for prioritization of areas for creation (or restoration) of small bodies of water, taking into account both ecological parameters (from species to landscape) and social ones. The method was developed in a test area $\left(130 \mathrm{~km}^{2}\right.$, in Canton Valais, Switzerland) representative of the Swiss Alpine landscapes and their associated socioeconomic activities.

The proposed methodological framework consists of four steps which allow refining the geographical area to propose two or three small areas (some hectares) suitable for the creation of small water bodies. The first step investigates the regional scale, often several thousand $\mathrm{km}^{2}$, with a focus on environmental considerations: presence of historical or contemporary wetlands and waterbodies, presence of cold stenotherm species, and favourable landscape (in terms of land use) and socioeconomic context. The second step identifies areas of biological connectivity between source ponds and future host ponds for cold stenotherm species, taking into account the distance between source and host ponds and landscape resistance to the movements of propagules, finally highlighting the migration corridors. The third step checks the preselected areas with the aim of discarding catchments impaired by selective or diffuse pollutions. The fourth and final step is intended to enhance the probability of the project's social acceptance: qualitative interviews and field observations are conducted on a local scale (often one $\mathrm{km}^{2}$ ) and options are evaluated with local stakeholders.

Conducting the four successive and complementary steps ensures that the selected areas have a high potential for hosting the alpine biodiversity, and furthermore provide a favourable social framework for success in the short as well as the long term. Such a tool should promote and facilitate actions for conserving freshwater biodiversity in the Alps.

\section{Introduction}

Climatic changes are expected to be a major driver of future changes in biodiversity in the Alps (Beniston 2012). Decline in geographic range will occur for cold stenotherm species, such as boreo-alpines, even leading to local extinction. In contrast, other species, including eurytherms, are already expanding their altitudinal range from lowland towards higher altitudes (e. g. Pauli et al. 2012). Freshwater biodiversity, already under major threat (Dudgeon et al. 2006), will be particularly impacted in the Alps (Rosset et al. 2010; Domisch et al. 2011; Rosset \& Oertli 2011). For pond communities, upward dispersal is realized through propagules (e. g. seeds, eggs, whole individuals or fragments thereof) which cross a terrestrial landscape to encounter new aquatic habitats in an altitudinal range higher than that of their origin. The colonization can be either active (e.g. flying as dragonflies or beetles, walking as amphibians) or passive (e.g. seed dispersal through wind, or epizoochory) (e.g. Bilton et al.

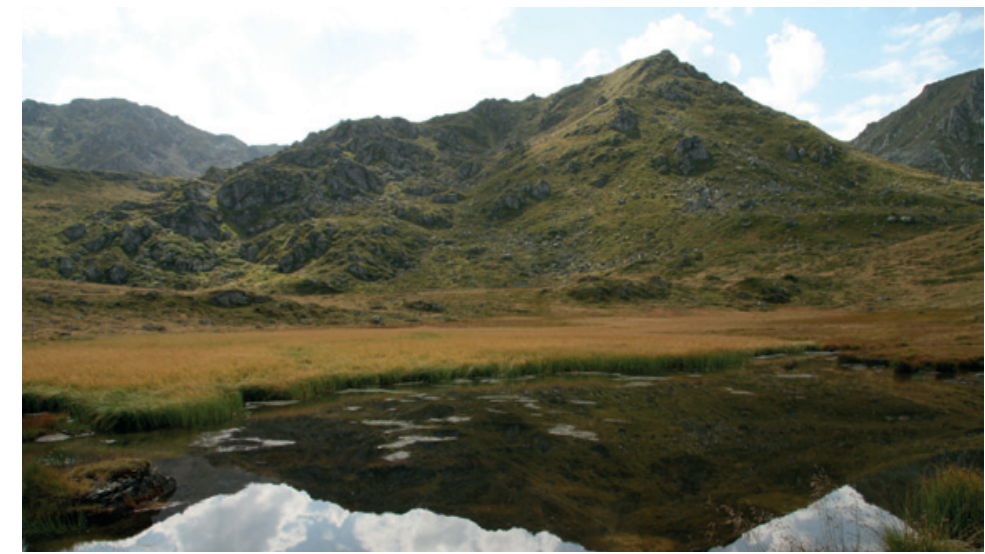

Figure 1 - A small Alpine waterbody from the study area, located at the Essertse (municipality of Hérémence, Canton Valais, Switzerland). Such ponds host boreoalpine species, threatened by the global warming. (C) 2011 / P.-A. Frossard

2001; Figuerola \& Green 2002; Frisch et al. 2007; Vanschoenwinkel et al. 2008; Waterkeyn et al. 2010).

Measures aimed at mitigating biodiversity in a changing environment include restoration efforts to 
conserve viable habitats but at the same time identify suitable stepping stone habitats for future colonization. This means also designing and creating new suitable habitats. Such emerging novel ecosystems ensure maintenance of ecological goods and services (Jackson \& Hobbs 2009), and are part of strategies for biodiversity conservation. However, restoring or creating new habitats is a costly and time-intensive process, often conflicting with other land uses. Therefore, prioritization of where endangered habitats may be viably restored or created can help to ensure the costeffectiveness of desired outcomes (Hyman \& Leibowitz 2000; Bolliger et al. 2009; Wilson et al. 2011). Maintaining ecosystem and landscape functioning, particularly functional connectivity, is important as the species will have to disperse for colonizing newly provided habitats and will have to move through the landscape to find the new habitats.

To foster the colonization of new habitats, management measures aim either at increasing the current density of ponds (new habitats or stepping stones) at higher altitudes than those of the ponds acting as sources, or at improving the connectivity between source and target ponds by reducing the resistance of the landscape to colonizer movements.

Increasing pond density is a common management practice, as creating new ponds compensates for the severe loss of up to $50 \%$ of ponds in recent centuries / decades (e.g. Oertli et al. 2005; Céréghino et al. 2008; Oertli et al. 2009; Boix et al. 2012). Wetland drainages also occurred in Alpine areas, leading to a decrease in pond densities.

Creating a new wetland is a management action that can be easily proposed, but its realization is a complex task. The multiple constraints can be quite varied in nature, from ecological (e. g. geology, topography, biological connectivity) to technical (pond construction) and socioeconomic (e.g. uses and social acceptance). Therefore one of the main challenges in creating new habitats is to find a suitable location which takes into account all constraints. Non-compliance with such a strategy would inevitably lead to failure.

We present a methodological framework for optimizing locations in the landscape to create new habitats, which will enable conservation managers to trade off various ecological and socioeconomic interests acting on mountainous areas. The method proposed here was developed and applied on the basis of ecological and socioeconomic investigations conducted in 2011 and 2012 in a study area $\left(130 \mathrm{~km}^{2}\right.$, in Canton Valais) representative of the landscapes of the Swiss Alps and their associated socioeconomic activities. The collected information included the distribution of boreo-alpine species, the landscape genetics of an umbrella species, a map of the biological connectivity of the ponds, an assessment of the water quality in the catchments and an investigation of social acceptance for restoration action.

\section{A methodological framework to prioritize pond creation / restoration in mountain regions}

A obvious preliminary step to the selection of favourable areas is to identify the targeted species, the cold stenotherm species threatened by climate change (Figure 2). Altitude or latitude are often used as surrogates of temperature (e. g. Cogbill \& White 1991; Körner 1998) and therefore the knowledge of altitudinal or latitudinal ranges of distribution of the species provides accurate assessments on the thermal requirements of the species and on their thermal sensitivity.

For example, in the species pools in Switzerland, Rosset \& Oertli (2011) identified 41 cold stenotherm (cold thermal specialist) species from three groups, aquatic plants (21 species), dragonflies (7 species) and aquatic beetles (13 species). No cold stenotherm species were identified in the Swiss species pool of amphibians and of aquatic snails. The 41 cold stenotherm species are presented in Appendix 1. These cold stenotherm species are all boreo-alpine species, distributed in the Alps and the boreal biogeographical region. None of the species is endemic to the Alps.

\section{Step 1. Considerations for habitat prioriti- zation on the regional scale}

The first step investigates the regional scale, often several thousand $\mathrm{km}^{2}$, representing for example a country, a canton or a protected area. Environmental considerations to conduct area prioritization include: presence of historical or contemporary ponds, presence of cold stenotherm species and favourable landscape (in terms of land use).

The aim of step 1 is to localize one restricted area favourable to pond restoration actions. The size of the area(s) should be in relation to the potential dispersal of the targeted cold stenotherm species. We propose here about $100 \mathrm{~km}^{2}$, as most dragonflies, beetles and plants species (three umbrella groups for ponds) cover dispersal ranges of at least $1 \mathrm{~km}$ distance (e.g. Corbet 1999; Rundle et al. 2002; Santamaría 2002).

Four types of environmental information are integrated, all preferably available in a GIS:

1.1 Localization of historical wetlands and ponds. Many waterbodies were drained or filled during the two last centuries. Historical maps provide information where wetlands were present in the past. Such areas are particularly suitable for creation (or restoration) of ponds, for ecological and social reasons: favourable substrate and geomorphologic conditions, potential seeds banks, a relatively high potential of social acceptance.

1.2 Localization of existing ponds. The existing ponds are the potential source of biodiversity (lowest altitudes) or / and the targets for species colonization (higher altitudes). Making use of pond data bases, e.g., regional inventories, aerial photographs. 
Preliminary step (i).

Identification of cold thermal specialists threatened by climate warming

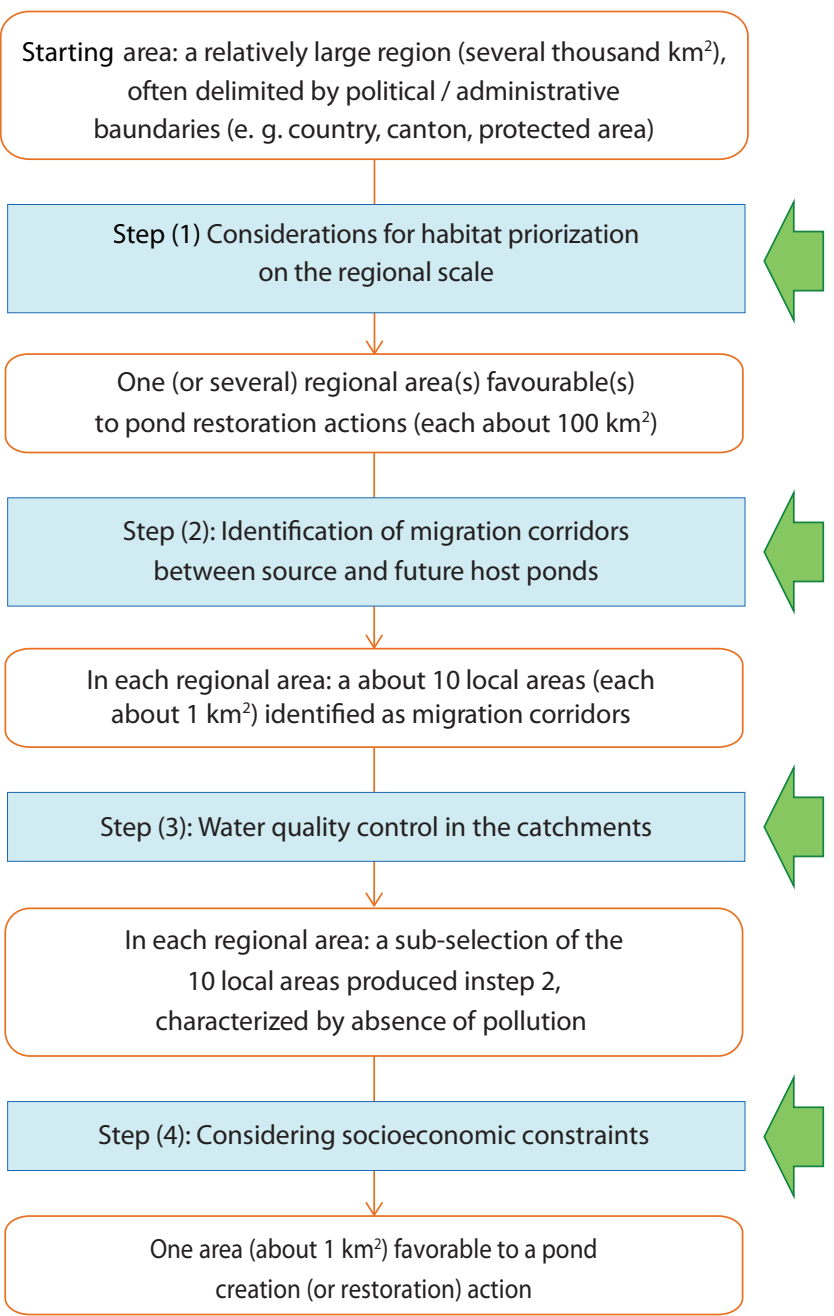

\section{Information to gather or to compile:}

\section{1 historical wetlands}

1.2 existing ponds

1.3 ponds hosting boreo-alpine species

1.4 landscape information (socio-economic

constrains or opportunities)

\section{1 source and future host ponds}

2.2 characterization of migration of targeted species 2.3 landscape mapping of functional connectivity

3.1 diffuse or punctual source of pollution in the catchments

3.2 analyses of the water in the targeted ponds

4.1 enquiries / interviews with municipal actors

4.2 enquiries / interviews with land-owners and other stakeholders

Figure 2 - Summary of the methodological framework for prioritizing areas for pond creation (or restoration).

1.3 Localization of the ponds hosting cold stenotherm species today. These alpine ponds are the source of colonizers. Presence of nearby source populations is a favourable factor for guaranteeing successful colonization of restored freshwater systems (e. g. Briers 2002; Brederveld et al. 2011). The aim is to identify a regional area potentially favourable (where cold stenotherm species are present), not to obtain exhaustive species inventories for all ponds. The information can be collected by investigating biological record centres (in Switzerland, for instance, the CSCF or InfoFlora) or asking regional experts for the target taxonomic groups. Most data are usually available for Odonata and aquatic plants, which may act as surrogates (or umbrellas) for other groups. A favourable area will be an area characterized by multiple sources of colonization, indeed by the presence of the species in as many waterbodies as possible.

1.4 Geographic information on key land use/land cover variables (including various types of forest and farmed land, recreational areas, settlements, infrastructures, cultural sites and vestiges, and protected areas of different categories) is collected and mapped on a regional scale. These different variables are analysed and interpreted as more or less constraining or favourable for pond creation or restoration from an environmental point of view.

Screening the starting area through steps 1.1 to 1.4 eventually produces a restricted geographical area (several tens of $\mathrm{km}^{2}$ ).

Application of step 1 to the example investigated in the Swiss Alps

The starting study area is the whole Canton Valais (Switzerland), where the administrative authorities in charge of nature conservation supported the project and aimed at the application of the produced deliverables. This canton is relatively large $\left(5224 \mathrm{~km}^{2}\right)$, with a wide altitudinal gradient (from 372 to $4634 \mathrm{~m}$ ), and is mainly mountainous (the Alps). 


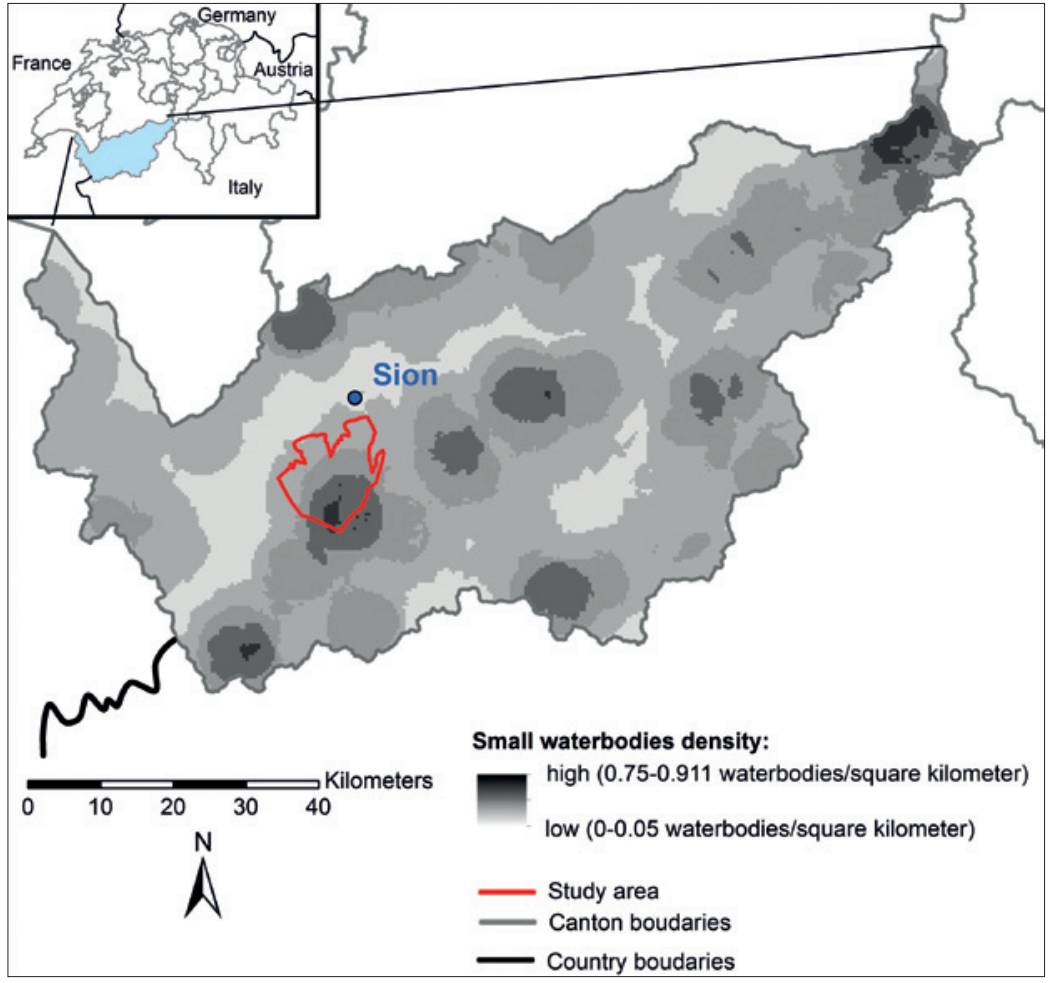

Figure 3-Density of small waterbodies (ponds and small lakes) in Canton Valais, Switzerland. Favourable areas are coloured, with highest densities indicated by a darker colour. The areas with few ponds (clearest colour) are discarded by the selection procedure of step 1 . The boundary of the area retained at the end of the selection procedure of step 1 is already indicated here.
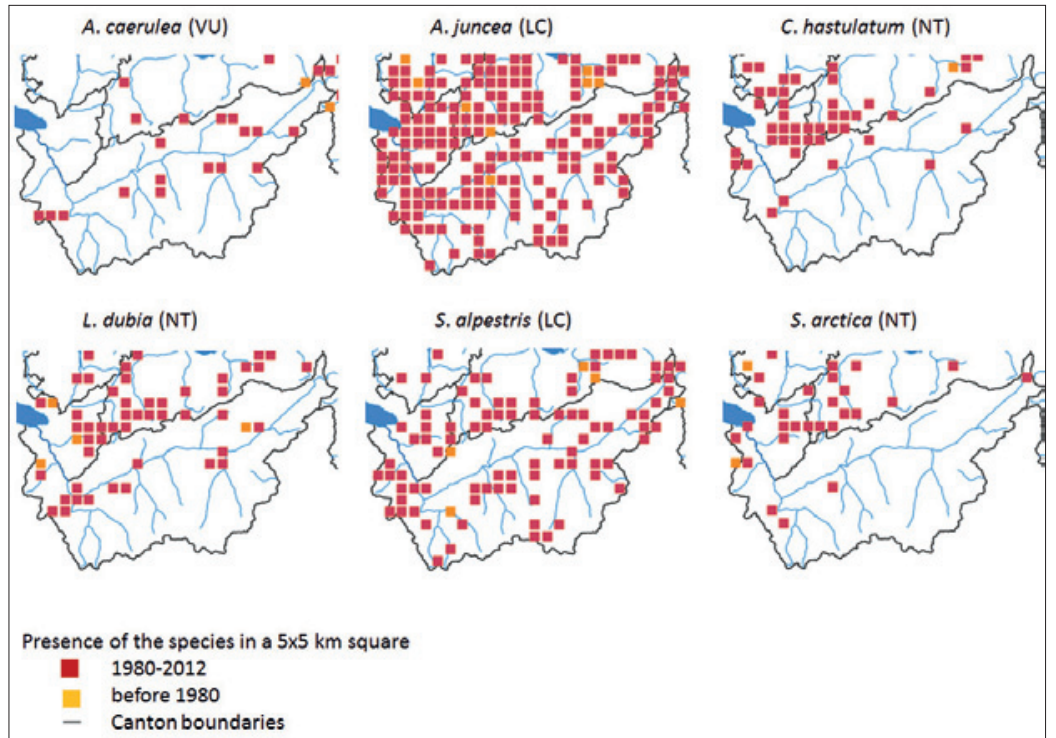

Figure 4 - Boreo-alpine dragonfly species: distributions of six species, Aeshna caerulea, A. juncea, Coenagrion hastulatum, Leucorrhinia dubia, Somatochlora alpestris, S. arctica, in the Canton Valais (Canton boundaries indicated with a black line), Switzerland. See Figure 3 for region localization. Data from CSCF. The seventh boreoalpine species, A. subarctica, was not observed and is therefore not presented here.

Presence of ponds. The densities and localizations of ponds (surfaces $>100 \mathrm{~m}^{2}$ ) were obtained through the databases lakes in the digital landscape model vector 25 of Switzerland. Additional information on a finer scale (e.g. smaller ponds) was provided by the prospection of ponds on satellite images conducted by Minssieux
(2009) within the framework of the project Important Areas for Ponds of the European Pond Conservation Network (Ewald et al. 2010a, 2010b). The cartography of pond density (Figure 3) highlights the potential regions favourable in the Canton Valais (indicated on the figure as coloured areas).

Presence of boreo-alpine species. Swiss databases are particularly rich in information on dragonfly distribution. Therefore the maps of the distribution of the boreo-alpine species (Figure 4) constitute an excellent tool. Two species are particularly well distributed in the region and are therefore selected as umbrella species for the further steps: Aeshna juncea and Somatochlora alpestris. Furthermore, the knowledge of the altitudinal distribution of $A$. juncea (Figure 5) indicates the lower limits of the regional area to select, i. e. $1500 \mathrm{~m}$.

The intersection of the distribution maps of the two species (i.e. Figure 4 restricted at altitude $>1500 \mathrm{~m}$ ) with the map of pond density (Figure 3) produces a set of squares representing regional areas favourable for the continuation of the selection procedure (Figure 6). The contiguous squares form areas, the four largest with a size each of about $150 \mathrm{~km}^{2}$. All these four regional areas are adequate for continuation to step 2. For logistic reasons (e.g. accessibility for sampling), the eastern ones of the four regional areas, i. e. the area Région des 4 Vallées (e.g. Figure 7) was selected for the next steps.

\section{Historical wetland}

This analysis has been made a posteriori of the analyses of the three other criteria selected for step 1 and has therefore been conducted only on the regional area issued of the screening with these three criteria. This analysis made it clear that the available historical data were not accurate and did not provide any useful information. We noticed that this criterion was taken into consideration at too late a stage and this is obviously an inaccuracy. The socioeconomic enquiries conducted throughout the study underline that this criterion is of crucial importance as it determines heritage values that can significantly enhance social acceptance for a pond restoration project. Therefore such historical data should be collected early in the screening process, conducted a priori (and not a posterior) to the screening through the three other criteria.

\section{Area selected through step 1}

Step 1 produced a regional area, locally called Région des 4 Vallées. It covers $130 \mathrm{~km}^{2}$ of the Swiss Alps in the Canton Valais (Figure 7), and is typical of the landscapes found elsewhere in the Swiss Alps. The altitudinal range considered falls between 1500 and $3300 \mathrm{~m}$. A total of 96 ponds (ranging in size from 100 to $20000 \mathrm{~m}^{2}$ ) has been identified in this region, representing a pond density of 0.7 ponds $/ \mathrm{km}^{2}$. This is a density close to the mean pond density in Switzerland (0.8 $/ \mathrm{km}^{2}$, Oertli \& Frossard 2013). Three catchment areas divide the study area, drained by the streams 
la Printse, la Fare and la Dixence. The landscape is mainly covered by forest stands, hay meadows, pastures below $2000 \mathrm{~m}$ and by alpine meadows, rhododendrons moors, snow beds and scree above $2000 \mathrm{~m}$. Nine municipalities share the area (Nendaz, Isérables, Riddes, Bagne, Hérémence, Vex, Les Agettes, Salins and Veysonnaz). The socioeconomy of the region is dominated by activities typical of these mountain regions, namely hydropower generation, winter tourism (e. g. skiing) or summer tourism (hiking, ATVs), grazing and forestry, drinking water production.

\section{Step 2. Identifying potential migration cor- ridors}

Starting with the area selected in step 1, this step 2 identifies a map of connectivity between source ponds and potential future host ponds, taking into account the distance between source and host ponds and landscape resistance to the movements of propagules. To produce this map, the following information has to be collected and analysed.

2.1. Localization of: (i) the source ponds hosting the cold stenotherm species today, and (ii) the host ponds situated at a higher altitude and supposed to host these species in the future. This is achieved through a field inventory of the presence or absence of the targeted cold stenotherm species in each pond.

2.2. Characterizations of the migration of the targeted cold stenotherm species. It is crucial to know the distance of potential dispersal and the resistance of the landscape elements to the movements of the propagules coming from the source ponds. The information is gathered through literature review and ideally complemented by field experimentation (e.g. mark-recapture, landscape genetics, least-cost path analyses...).

2.3. Based on 2.1 and 2.2, a connectivity map is developed, highlighting likely functional corridors between source and targeted ponds. These corridors are the ecologically favourable areas for hosting habitats (= selected areas with step 2 ) that could easily (and quickly) be colonized by propagules/individuals from the source ponds and therefore are favourable for acting as habitats and stepping stones toward the targeted ponds.

Application of step 2 to the example investigated in the Swiss Alps

To produce the map of biological connectivity in the regional area (Région des 4 Vallées) selected by step 1 , the following information was collected.

ad 2.1. The localization of source ponds and of the targeted ponds was achieved through a field inventory of the presence or absence of the species in each pond. Floristic and faunistic inventories were realized in 39 ponds of the regional area during summer 2011 and 2012, with an altitudinal
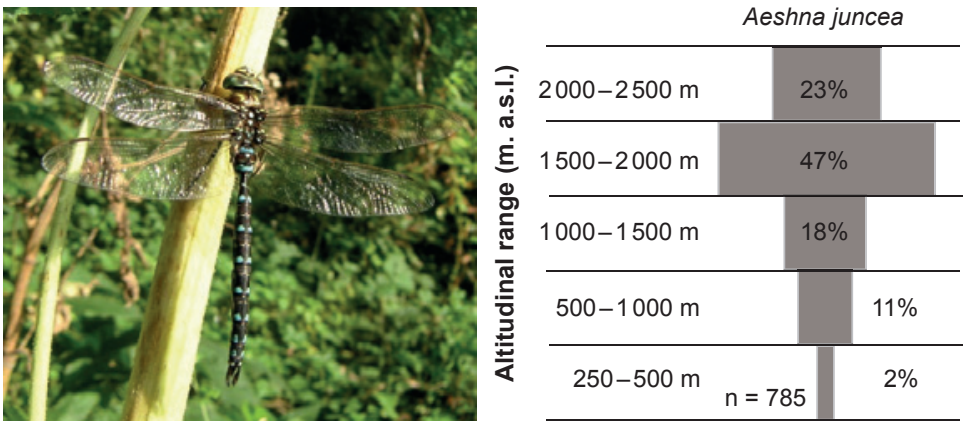

Figure 5 - Altitudinal distribution in Switzerland of the widespread boreoalpine dragonfly Aeshna juncea (Oertli 2010). The data report 785 observations of exuviae and subaldults, two life stages attesting the reproduction at the observed altitude. Data were gathered mainly between 1990 and 2002 by the Swiss Centre for Fauna Cartography.

Table 1 - List of boreo-alpine species occurring in 39 sampled ponds, with frequency (\% of 39) and mean abundance (in occupied pond). * Carex nigra is a eurytherm species but is included here in the pool of boreo-alpine species because its distribution in Switzerland is mainly restricted to mountain areas.

\begin{tabular}{|l|r|l|}
\hline Boreo-alpine species & $\begin{array}{l}\text { Frequency (\% from } \\
\text { 39 ponds) }\end{array}$ & Density/occupied pond \\
\hline & & $\begin{array}{l}\text { Density class: } \\
1: 1 \text { to 3 individuals; } \\
2: 4 \text { to 10; } \\
3>10\end{array}$ \\
\hline Aquatic plants & $3 \%$ & 1.0 \\
\hline Carex frigida & $74 \%$ & 2.5 \\
\hline Carex nigra* & $5 \%$ & 1.5 \\
\hline Epilobium nutans & $15 \%$ & 2.2 \\
\hline Eriophorum angustifolium & $28 \%$ & 2.4 \\
\hline Eriophorum scheuchzeri & $13 \%$ & 2.2 \\
\hline Juncus filiformis & $3 \%$ & 1.0 \\
\hline Ranunculus reptans & $23 \%$ & 1.4 \\
\hline Saxifraga stellaris & & mean number of individuals \\
\hline Aquatic Coleoptera (Dytiscidae) & $8 \%$ & 1 \\
\hline Agabus lapponicus & $10 \%$ & 2.5 \\
\hline Hydroporus foveolatus & $5 \%$ & 2.5 \\
\hline Hydroporus nigrita & $21 \%$ & 9.5 \\
\hline Stictotarsus griseostriatus & & mean number of individuals \\
\hline Odonata & $5 \%$ & 6.5 \\
\hline Aeshna caerula & $36 \%$ & 4.7 \\
\hline Aeshna juncea & $15 \%$ & 3.7 \\
\hline Aeshna juncea (A) & & 1.2 \\
\hline Leucorrhinia dubia (A) & $3 \%$ & \\
\hline Somatochlora alpestris & & \\
\hline
\end{tabular}

range from 1550 to $2780 \mathrm{~m}$. A total of 16 boreoalpine species were observed (Table 1), the most frequent being the aquatic plant Carex nigra $(74 \%$ of the ponds) and the dragonfly A. juncea (36\% of the ponds). The boreo-alpine species are well represented in the study area between 1500 and $2500 \mathrm{~m}$ (Figure 8), even if their distribution is uneven due to the patchy distribution of the ponds. Notice that the inventory also allowed detecting new ponds not identified in step 1 . The selected area includes about ten different types of protected areas, of various federal, cantonal or communal protection status (Figure 8). Most of these areas are potentially favourable to the creation of new waterbodies, but some have been evaluated 


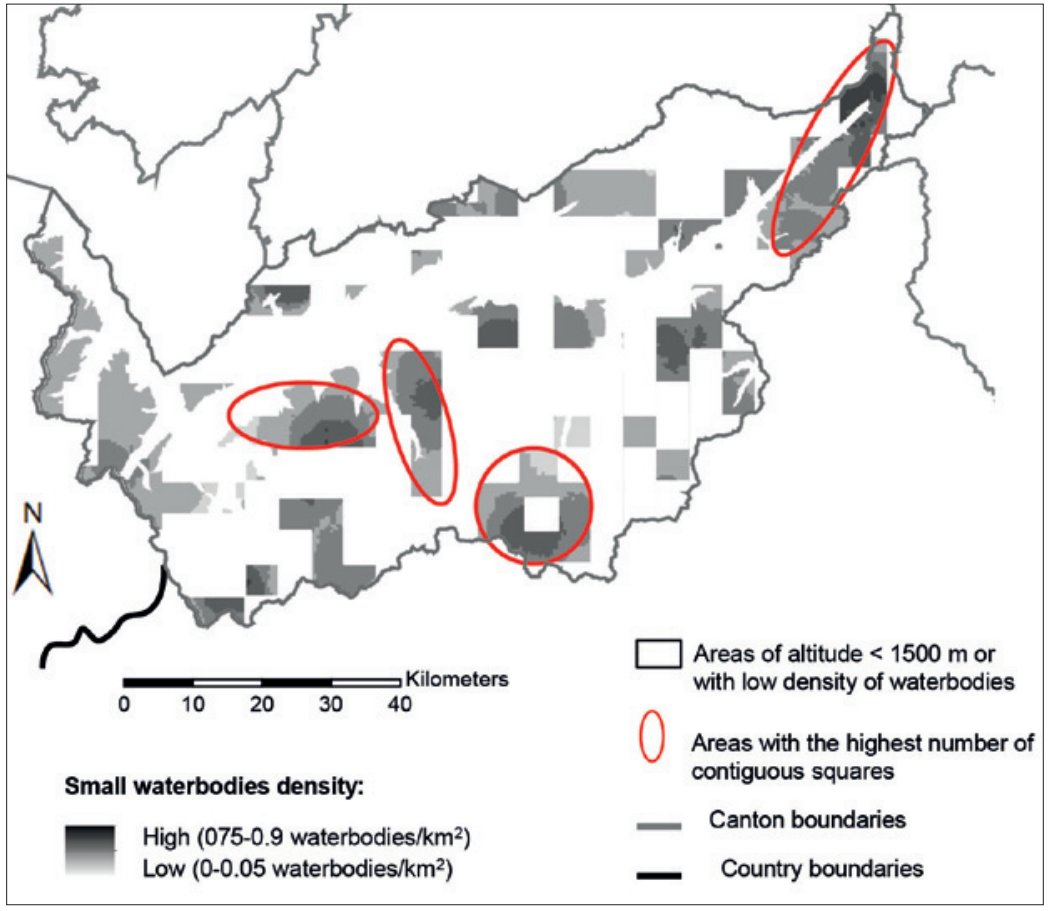

Figure 6 - Map highlighting the intersection (grey colour) of (i) map of pond densities (i.e. Figure 2; only altitude $>1500 \mathrm{~m}$ ), with (ii) map of presence of Aeshna juncea and Somatochlora alpestris (i. e. Figure 3). The four areas presenting the highest number of contiguous squares are evidenced here by red ellipses. See Figure 3 for region localization.

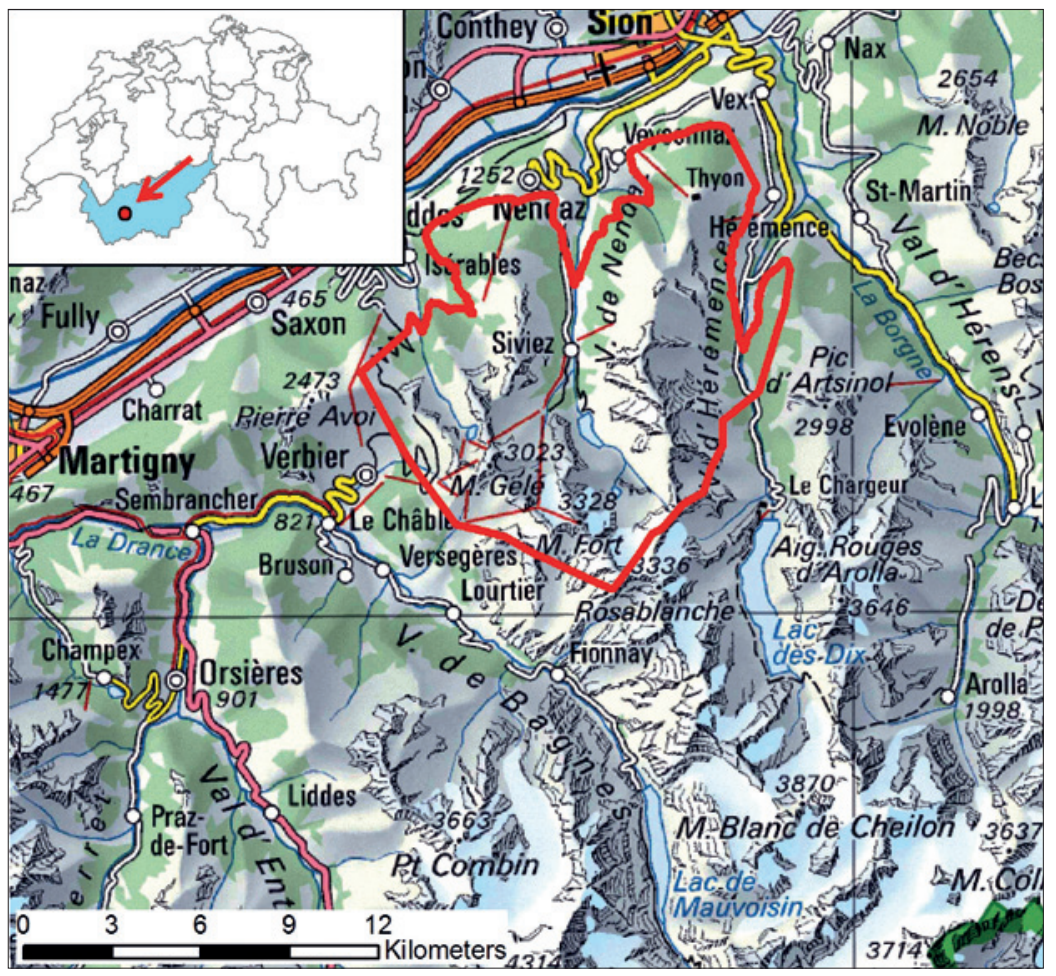

Figure 7 - Location of the investigated area (Région des 4 Vallées) in the Alps from the Canton Valais (Switzerland). Map reproduced by permission of swisstopo (BA13130).

as less favourable according to their conservation objectives, such as dry grasslands or wetlands.

ad 2.2. The assessment of the dispersion distance of the targeted boreo-alpine species was realized through two complementary approaches: (i) bibliographic review, (ii) landscape genetic of the most frequent species in the investigated ponds, an emergent aquatic plant, the black sedge C. nigra.

\section{Bibliographic review}

The bibliographic review on dispersal distances for inhabitants of ponds rendered convergent values, from about one kilometre for weak dispersers (e.g. caddisflies, stoneflies, aquatic plants, damselfly; Briers et al. 2004; Winterbourn et al. 2007; Brederveld et al. 2011; Didham et al. 2012; Keller et al. 2012) to several kilometres for powerful dispersers (e.g. dragonflies; Corbet 1999).

\section{Landscape genetics}

Landscape-genetic analyses were conducted with C. nigra with the aim of linking the gene flow to landscape structures and for detecting functional corridors. Genetic profiling of 255 C. nigra individuals from 23 ponds was carried out in 2011 using single sequences repeats ISSR profiling. Details of analytical procedures and of results are presented in Crovadore et al. (in prep.). STRUCTURE was applied (Pritchard et al. 2000) to assess broad-scale genetic patterns. It turns out that six classes fulfil the statistical criteria required. Nevertheless these detected patterns do not become effective in a spatial context (Figure 9). Furthermore, no relationship could be identified between straight-line geographic distance and genetic differentiation. Thus the genetic pattern is independent of the distances between the ponds.

The results underline that no landscape patterns can be proposed on the bases of genetic analyses of C. nigra populations. This suggests that the populations are not clearly separated and that the dispersal is maybe efficient between the ponds of the studied area.

\section{Distances of migration}

The results of step 2.2 (literature review and field investigation with $C$. nigra) indicate that plants and animals disperse relatively well on the scale of the studied area $\left(130 \mathrm{~km}^{2}\right)$, with most taxa dispersing easily over distances of several hundred metres.

ad 2.3. The results of step 2.1 (localization of sources and targeted ponds) and 2.2 (dispersal distance of the species) were then coupled with information on resistance of the landscape to dispersal. Two umbrella groups were considered, i. e. dragonflies and aquatic beetles. Information on the degree of resistance of the various landscape elements to the flight of these insects was provided by experts. A connectivity map was then produced for each taxonomic group (Figure 10A and 10B), highlighting the areas of connectivity between source and targeted ponds which represent the migration corridors. These corridors are the potential ecologically favourable areas for pond creation or restoration. The intersection of the two map provided the final areas retained with this step 2 (Figure 10C). 


\section{Step 3. Water quality control in the catch- ments}

A restoration project aims at producing good quality habitats. Therefore, the local areas preselected in step 2 have to be checked for their potential impairment. The objectives of this step 3 will be:

the identification of potential diffuse (e.g. landuse) or localized (e.g. wastewater discharge) sources of pollution as nutrients or agro-toxics; the analyses of the water quality of the targeted ponds by altitude, with focus on heavy metals, as high-altitude bodies of water from other parts of the Alps have been shown to be highly polluted (e.g. through nickel; Thies et al. 2007; Camarero et al. 2009).

This step will therefore potentially remove some of the areas selected in step 2 , if evidence of pollution or potential pollution are found.

Application of step 3 to the example investigated in the Swiss Alps

Sources of diffuse or selected pollution. Investigations of the land uses and of human activities in the catchments of the selected areas in step 2 (cf. Figure 10) returned no sources of pollution. The land use is mainly extensive agriculture (cattle grazing), forestry and tourism, with few fertilizer applications. Buildings (barns, farms) have controlled effluents, none threatening the selected areas.

\section{Water analyses of targeted ponds}

Analyses were conducted in July and August 2011 on the three main catchments. A total of 12 water samples were taken from 3 ponds situated at altitudes of $2440 \mathrm{~m}, 2545 \mathrm{~m}$ and $2780 \mathrm{~m}$ respectively. Analyses (Inductively Coupled Plasma - Optical Emission Spectroscopy) were conducted for nine metals: As, $\mathrm{Cd}, \mathrm{Cu}, \mathrm{Hg}, \mathrm{Ni}, \mathrm{Pb}, \mathrm{Se}$, Ti and $\mathrm{Zn}$. All concentrations were below the limit of detectability of the measuring devices, a sign of very good water quality with regard to heavy metals.

In conclusion, all areas selected in step 2 are potentially without threat of pollution and can therefore be retained for step 4 .

\section{Step 4. Considering socioeconomic con- straints for habitat prioritization}

The final step (4) concentrates on the project's social acceptance. Social considerations are already to be taken into consideration as preliminaries of steps 1 to 3 , with several actions to be undertaken. For example, information about the research, its objectives, partners and methods is communicated to the municipalities of the areas where ponds are sampled and corridors identified (steps 2.1 to 2.3). Appropriate information support can also be distributed to other regional stakeholders.

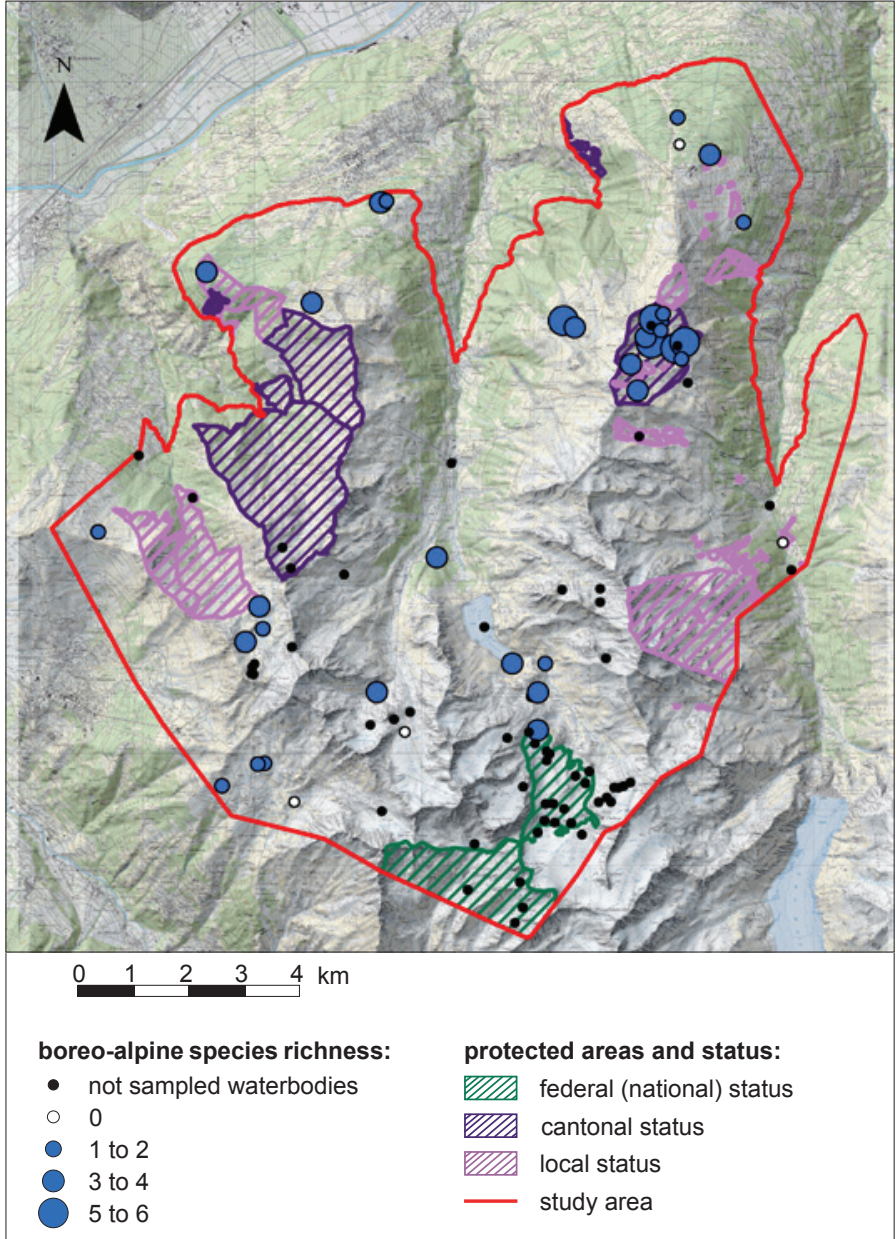

Figure 8-Map of richness in boreo-alpine species in the 39 investigated ponds and protected areas. The boreo-alpine species $=$ aquatic plants + aquatic beetles + dragonflies i.e. Table 1. Map reproduced by permission of swisstopo (BA13130). Data on protected areas with federal status from the Federal office for Environment.

Social considerations are particularly relevant and requisite at the final steps of selections. Step 4 aims at screening the areas selected in step 3 with a social filter to arrive at one final area. Qualitative interviews and field observations are conducted on a fine scale (often just $1 \mathrm{~km}^{2}$ ). Perceptions about existing conflicts and values are analysed and preferences for future options evaluated with local stakeholders, owners, users, managers and decision makers. Multiple use strategies are co-constructed in order to enhance the acceptance and with it the feasibility and the sustainability of the pond creation or restoration project. Indeed, the sustainability of a restoration project depends on whether local people perceive it as providing them with some direct benefit (Aronson et al. 2010). Also local actors can see the project as a way to innovate and create new options for the development of the territory by mobilizing collective social capacities (Finger-Stich 2009).

The finally selected area is the one that offers the best social acceptance of a pond restoration project.

The precise localization of the restoration project in this selected area is eventually achieved by assessing the technical criteria necessary for the restoration or 


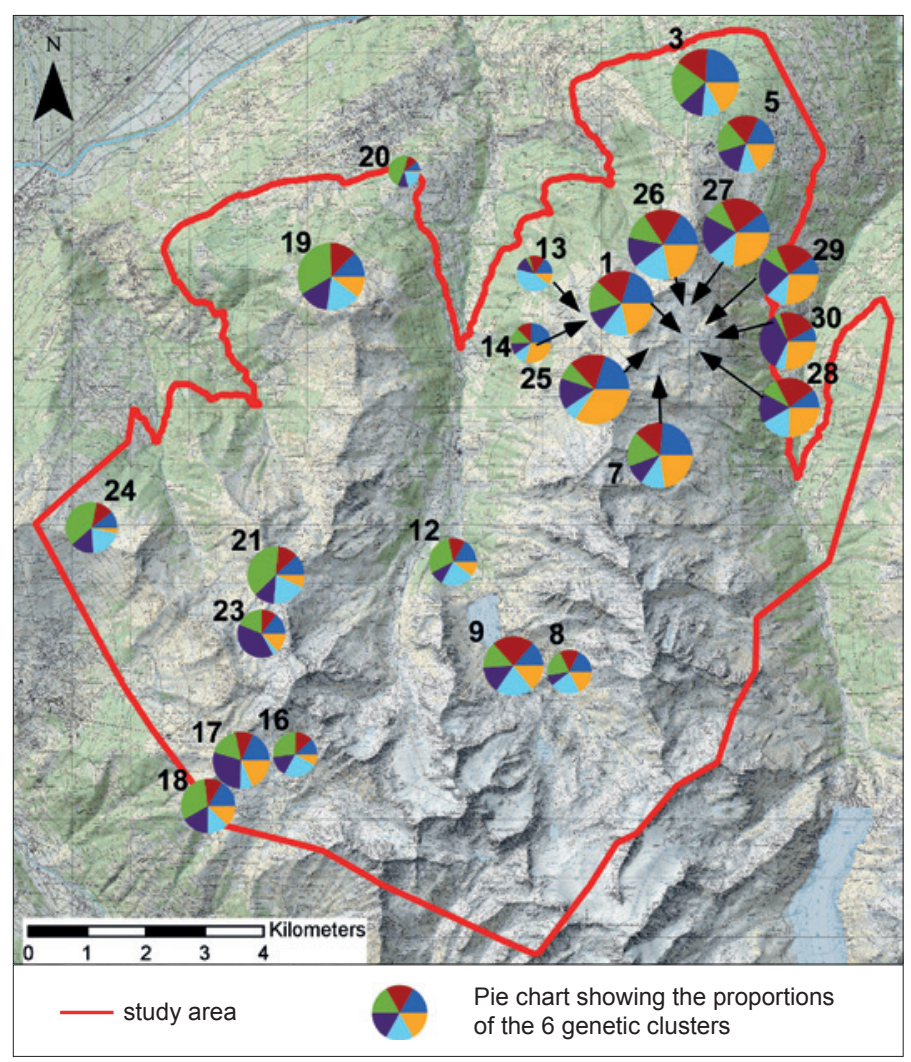

Figure 9 - Spatial representation of the six genetic clusters of Carex nigra. The sizes of the pie charts are proportional to the number of individuals used for the genetic analysis. The arrows show the location of the pond presented by the pie chart. Numbers are the pond reference numbers of each diagram. Map reproduced by permission of swisstopo (BA13130).

construction of a permanent pond, linked for example to topography, geology and hydrology.

Application of step 4 to the example investigated in the Swiss Alps

The entire study region (Canton of Valais) is considered as socioeconomically favourable, the local conservation authorities are looking for sites for undertaking restoration actions, such as creating ponds or wetlands. These actions are mitigation measures for developments of touristic or industrial activities.

Qualitative semi-structured interviews were conducted on a local scale, in 2012, on the areas selected in step 3, meeting first with representatives from seven municipalities of the region in order to evaluate their potential acceptance of the restoration or creation of new ponds in their municipality. Acceptance was evaluated on the basis of responses obtained on questions assessing the:

institutional support at municipal level,

availability of economic resources,

demand for multiple water uses,

local heritage values related to water.

The results are synthesized in a simple matrix (Table 2) and the degree of acceptance of the different municipalities mapped on the final selection map of the project.
The most favourable area issued from this socioeconomic step is shown in Figure 11, however the formal approval for a project to be realized in this municipality rests on its local decision-making process. It is also the area finally selected through the screening of the four steps of this selection methodology. With the agreement of local authorities, researchers then met with land owners and land users of the remaining selected areas in order to define collaboratively conditions in which the creation or restoration of a pond is most suitable to the site and in agreement with their land uses and their preferences.

\section{Application to the example investigated in the Swiss Alps: description of selected areas}

Three areas of about one hectare each were finally selected by applying the four selection steps of the proposed methodology (Figure 11). They are situated at altitudes of 2198, 2130 and $2147 \mathrm{~m}$ respectively. All these areas are located in alpine meadows which are used extensively for grazing. Several hiking paths and ski runs cross these areas. These corridors connect source ponds number 19, 20, 33, 34, and 35 (altitude 1570 to $2171 \mathrm{~m}$ ), which host boreo-alpine species (Coleoptera: Stictotarsus griseostriatus; Odonata: A. juncea, Leucorrbinia dubia, S.alpestris), with the targeted ponds 21, 22 and 23, as well as with several noninvestigated ponds located at altitudes between 2475 and $2750 \mathrm{~m}$.

\section{Discussion}

The application of this method allows evaluating the importance of existing ponds for hosting threatened biodiversity and indicates the best localizations for restoration and creation of new ponds, taking into account the varying local socioeconomic uses of Alpine aquatic ecosystems.

The development of the method, based on a local case study in the Canton Valais (Switzerland), highlighted some key points to consider in such approaches.

First, from an ecological point of view, the application of such a method of localizing favourable areas for restoration needs many prerequisites, which are not always available. This underlines the need for more research on topics providing basic information for applied conservation actions. For example, it is

Table 2 - Matrix highlighting the degree of acceptance in the seven municipalities ( $A$ to $F$ ) for four social criteria. -1 least acceptance, 2 bighest acceptance, empty fields indicate absence of data.

\begin{tabular}{|l|r|r|r|r|r|r|r|}
\hline Municipalities & A & B & C & D & E & F & G \\
\cline { 1 - 6 } Criteria & & & & & & & \\
\hline i) Institutional support at municipal level & -1 & 2 & 1 & 2 & & 2 & 2 \\
\hline ii) Availability of economic resources & 2 & 2 & & 2 & & & 2 \\
\hline iii) Demand for multiple water uses & 2 & 2 & 2 & 2 & 2 & 2 & 2 \\
\hline iv) Local heritage values related to water & 2 & 2 & 2 & 2 & 2 & 2 & 2 \\
\hline
\end{tabular}




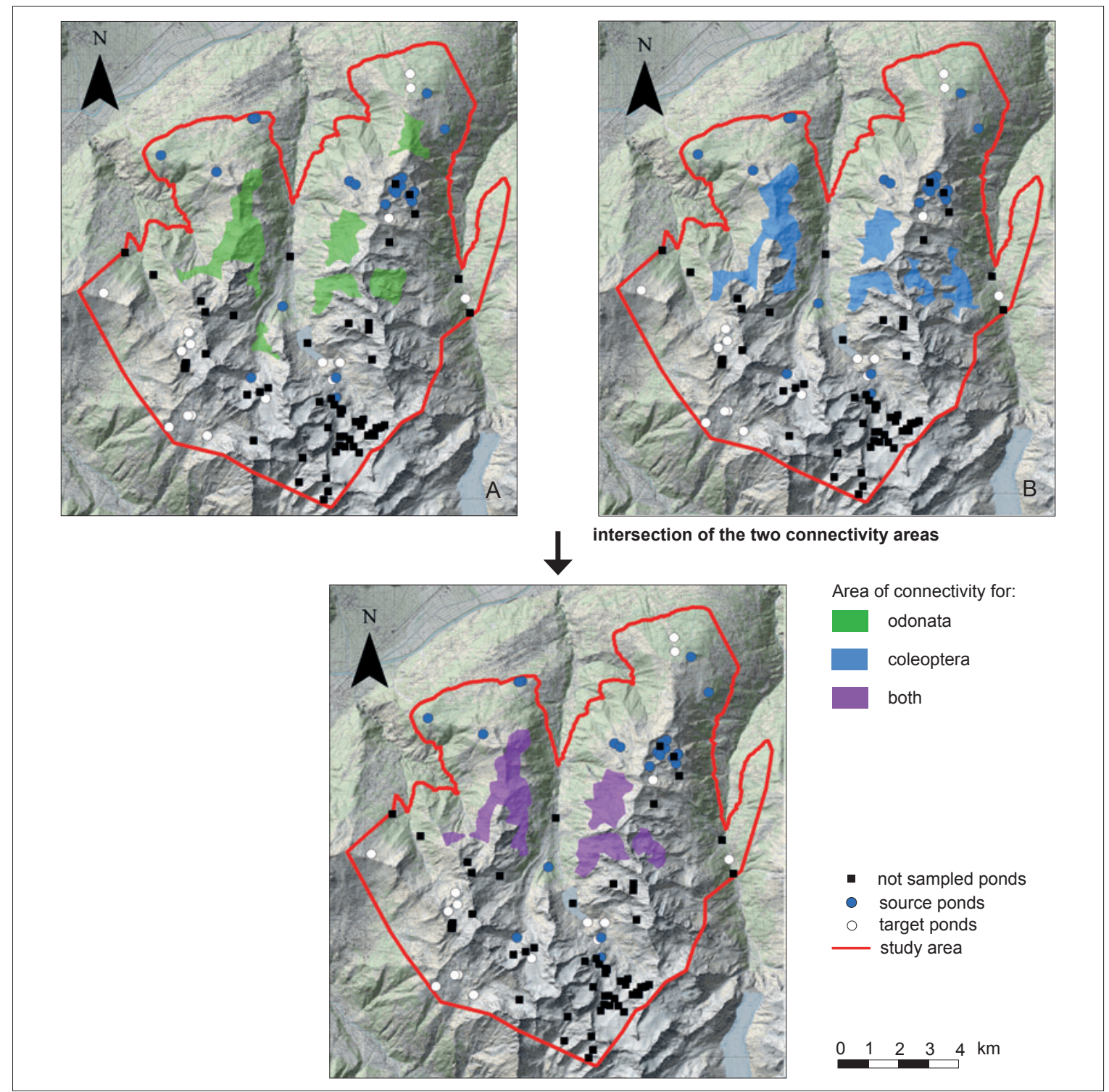

Figure 10 - Maps of areas of connectivity between source and target ponds produced by step 2 for the umbrella groups used here as tools: dragonflies (A), beetles (B), dragonflies and beetles (C). These maps integrate the information produced by step 2.1 (localization of source and target ponds) and step 2.2 (distance of dispersal of the species), and are coupled with information on resistance of the landscape to dispersal (step 2.3). The final selected areas (map C) is produced by intersecting map A with map B. Map reproduced by permission of swisstopo (BA13130).

evident that dispersal of organisms is insufficiently documented. Biodiversity includes diverse taxa and therefore highly diversified temporal and spatial strategies for dispersal and colonization of new habitats (pathways, distances). Landscape genetics can provide useful information but are too expensive to be applied to a broad number of species. Other, more traditional, techniques like marking can constitute useful complementary approaches. Another key topic is the availability of data on species distribution. This relies on the existence of administrative structures that organize existing data and promote their collection, in Switzerland, for example, the biological record centres InfoFlora and CSCF. As they often rely on volunteers' data, this implies that networks of volunteers exist and are active. Volunteers, however, often focus on flagship groups (such as amphibians, dragonflies, plants).
Subsequent work on those flagship groups is then based on the assumption (rarely tested) that they are also umbrella groups.

Second, for the social acceptance of a pond restoration project, it has to contribute to the overall development and political goals of local and regional actors. The study of land uses and social acceptance is particularly relevant at municipal level. Another finding is that the threat of global warming and its impacts on biodiversity are not readily perceived as a local issue. Therefore such a pond restoration project should address other local interests than just those pertaining to climate change adaptation, for example, the pragmatic need of municipalities to respond to an institutionalized demand for environmental compensation measures. Further, social acceptance is the result of a historical process - it is not given - it emerges through 


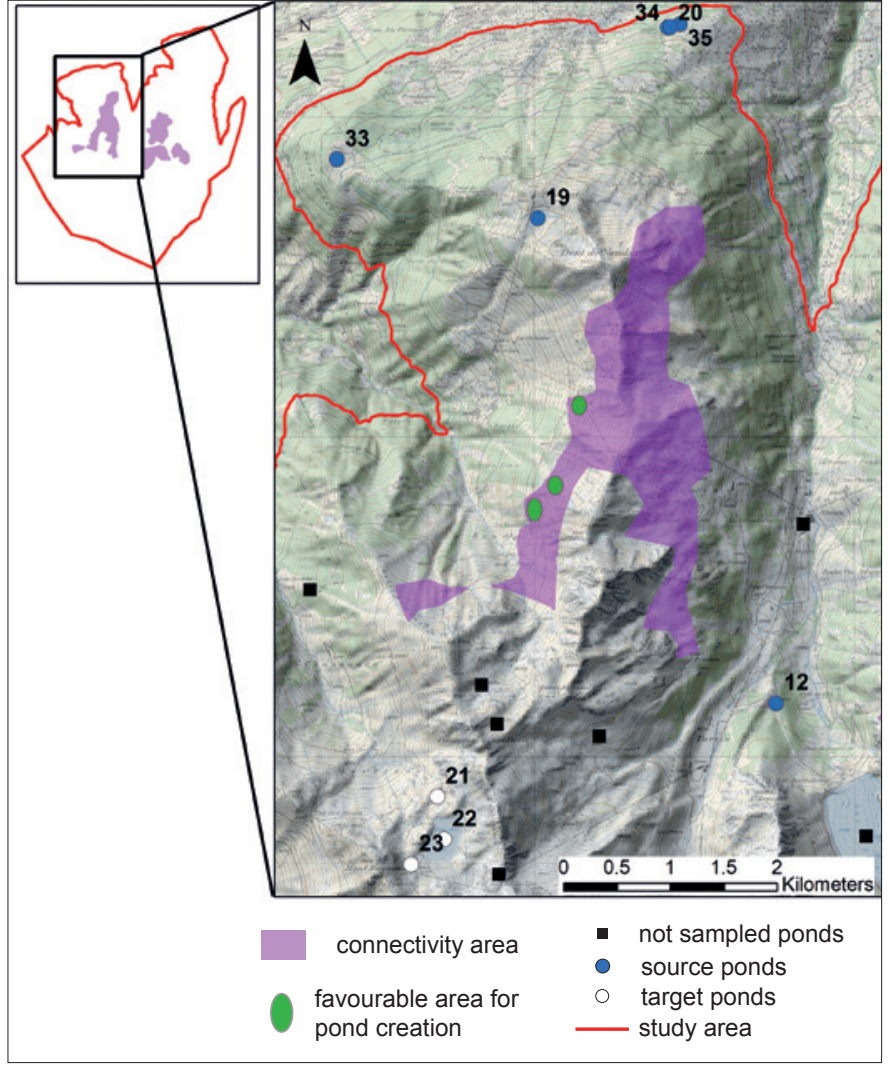

Figure 11 - Localization of the three selected areas favourable for pond creation. The source and target ponds are also indicated. Numbers are the pond reference numbers of the source and target ponds. Map reproduced by permission of swisstopo (BA13130).

social interactions, building on the social capacity of communities to solve conflicts around the use of natural resources and on local heritage value related to freshwater and water bodies.

The next step will now be to put the produced methodology into practice on the selected study site. The creation of the new bodies of water should then be monitored in order to measure success, for the boreo-alpine species and for the local socioeconomic activities. Based on these results, further application and tests of the method will be encouraged in other regions of the Alps. The methodological framework for prioritization of restoration areas proposed here should promote and facilitate actions for conserving freshwater biodiversity in the Alps.

\section{Acknowledgements}

We are grateful for the help of several people that have assisted in the field or in the lab, and in particular Amélie Achard and Jérôme Weber. Many valuable insights were provided on the development of the methodology by a support group, composed of Lionel Sager (InfoFlora), Christian Monnerat (CSCF) and Daniel Küry (LifeSciences). We would like to thank the Canton of Valais for their collaboration in the frame of this project.

\section{References}

Aronson, J., J.N. Blignaut, S.J. Milton, D. Le Maitre, K.J. Esler, A. Limouzin, C. Fontaine, M.P. De Wit, W. Mugido, P. Prinsloo, L. Van Der Elst, \& N. Lederer 2010. Are Socioeconomic Benefits of Restoration Adequately Quantified? A Meta-analysis of Recent Papers (2000-2008) in Restoration Ecology and 12 Other Scientific Journals. Restoration Ecology 18: 143-154.

Beniston, M. 2012. Changements climatiques et impacts. De l'échelle globale à l'échelle locale. Lausanne.

Bilton, D.T., J.R. Freeland \& B. Okamura 2001. Dispersal in freshwater invertebrates. Annual Review of Ecology and Systematics 32: 159-181.

Boix, D., J. Biggs, R. Céréghino, A. Hull, T. Kalettka \& B. Oertli 2012. Pond research and management in Europe: "Small is Beautiful". Hydrobiologia 689: 1-9.

Bolliger, J., T. Dalang, T.C. Edwards, E. Meier \& F. Kienast 2009. Assessing reforestation risks in dry grasslands of high conservation priority: challenges for management strategies. Salzburg, Bratislava.

Brederveld, R.J., S.C. Jähnig, A.W. Lorenz, S. Brunzel \& M.B. Soons 2011. Dispersal as a limiting factor in the colonization of restored mountain streams by plants and macroinvertebrates. Journal of Applied Ecology 48: 1241-1250.

Briers, R.A. 2002. Incorporating connectivity into reserve selection procedures. Biological Conservation 103: 77-83.

Briers, R.A., J.H.R. Gee, H.M. Cariss \& R. Geoghegan 2004. Inter-population dispersal by adult stoneflies detected by stable isotope enrichment. Freshwater Biology 49: 425-431.

Camarero, L., I. Botev, G. Muri, R. Psenner, N. Rose \& E. Stuchlik 2009. Trace elements in alpine and arctic lake sediments as a record of diffuse atmospheric contamination across Europe. Freshwater Biology 54: 2518-2532.

Céréghino, R., J. Biggs, B. Oertli \& S. Declerck 2008. The ecology of European ponds: defining the characteristics of a neglected freshwater habitat. Hydrobiologia 597: 1-6.

Cogbill, C.V. \& P.S. White 1991. The latitude elevation relationship for spruce-fir forest line along the Appalachian mountain chain. Vegetatio 94: 153-175.

Corbet, P.S. 1999. Dragonflies. Behaviour and ecology of Odonata. Colchester.

Didham, R.K., T.J. Blakely, R.M. Ewers, T.R. Hitchings, J.B. Ward \& M.J. Winterbourn 2012. Horizontal and vertical structuring in the dispersal of adult aquatic insects in a fragmented landscape. Fundamental and Applied Limnology 180: 27-40.

Domisch, S., S.C. Jähnig \& P. Haase 2011. Climatechange winners and losers: stream macroinvertebrates of a submontane region in Central Europe. Freshwater Biology 56: 2009-2020.

Dudgeon, D., A.H. Arthington, M.O. Gessner, Z. I. Kawabata, D.J. Knowler, C. Leveque, R.J. Naiman, A.H. Prieur-Richard, D. Soto, M.L.J. Stiassny \& C.A. 
Sullivan 2006. Freshwater biodiversity: importance, threats, status and conservation challenges. Biological Reviews 81: 163-182.

Ewald, N., P. Nicolet, B. Oertli, V. Della Bella, L. Rhazi, A.-S. Reymond, E. Minssieux, E. Saber, M. Rhazi, J. Biggs, N. Bressi, R. Cereghino, P. Grillas, T. Kalettka, A. Hull, O. Scher \& L. Serrano 2010a. A preliminary assessment of Important Areas for Ponds (LAPs) in the Mediterranean Basin and Alpine Arc. Site profiles. Technical Report, European Pond Conservation Network (EPCN).

Ewald, N., P. Nicolet, B. Oertli, V. Della Bella, L. Rhazi, A.-S. Reymond, E. Minssieux, E. Saber, M. Rhazi, J. Biggs, N. Bressi, R. Cereghino, P. Grillas, T. Kalettka, A. Hull, O. Scher \& L. Serrano 2010b. A preliminary assessment of Important Areas for Ponds (LAPs) in the Mediterranean Basin and Alpine Arc. Technical Report. Technical Report, European Pond Conservation Network (EPCN).

Figuerola, J. \& A.J. Green 2002. Dispersal of aquatic organisms by waterbirds: a review of past research and priorities for future studies. Freshwater Biology 47: 483-494.

Finger-Stich, A. 2009. Innovation in the plural of the alpine cre-a(c)tors. Journal of Alpine Research 97. Available at: http://rga.revues.org/index817.html

Frisch, D., A.J. Green \& J. Figuerola 2007. High dispersal capacity of a broad spectrum of aquatic invertebrates via waterbirds. Aquatic Sciences 69: 568-574.

Hyman, J.B. \& S.G. Leibowitz 2000. A General Framework for Prioritizing Land Units for Ecological Protection and Restoration. Environmental Management 25: 23-35.

Jackson, S.T. \& R.J. Hobbs 2009. Ecological Restoration in the Light of Ecological History. Science 325: 567-569.

Keller D., M.J. Van Strien \& R. Holderegger 2012. Do landscape barriers affect functional connectivity of populations of an endangered damselfly? Freshwater Biology 57: 1373-1384.

Körner, C. 1998. A re-assessment of high elevation forest line position and their explanation. Oecologia 115: 445-459.

Minssieux, E. 2009. Développement d'une méthodologie pour l'identification des zones d'importance pour les étangs et les mares en Europe : application à l'Arc Alpin. Master thesis. University of Lyon I, Lyon.

Oertli, B. 2010. The local species richness of Dragonflies in mountain waterbodies: an indicator of climate warming? BioRisk 5: 243-251.

Oertli, B., J. Biggs, R. Céréghino, P. Grillas, P. Joly $\&$ J.B. Lachavanne 2005. Conservation and monitoring of pond biodiversity: introduction. Aquatic Conservation: Marine and Freshwater Ecosystems 15: 535-540.

Oertli, B., R. Cereghino, A. Hull \& M.R. Miracle 2009. Pond conservation: from science to practice. $H y$ drobiologia 634: 1-9.

Oertli, B. \& P.-A. Frossard 2013. Les mares et étangs : écologie, conservation, gestion, valorisation. Lausanne.
Pauli, H., M. Gottfried, S. Dullinger, O. Abdaladze, M. Akhalkatsi, J.L.B. Alonso, G. Coldea, J. Dick, B. Erschbamer, R.F. Calzado, D. Ghosn, J.I. Holten, R. Kanka, G. Kazakis, J. Kollár, P. Larsson, P. Moiseev, D. Moiseev, U. Molau, J. M. Mesa, L. Nagy, G. Pelino, M. Puşcaş, G. Rossi, A. Stanisci, A. O. Syverhuset, J.-P. Theurillat, M. Tomaselli, P. Unterluggauer, L. Villar, P. Vittoz \& G. Grabherr 2012. Recent Plant Diversity Changes on Europeans Mountain Summits. Science 336: 353-355.

Pritchard, J.K., M. Stephens \& P. Donnelly 2000. Inference of population structure using multilocus genotype data. Genetics 155: 945-959.

Rosset, V., A. Lehmann \& B. Oertli 2010. Warmer and richer? Predicting the impact of climate warming on species richness in small temperate waterbodies. Global Change Biology 16: 2376-2387.

Rosset, V. \& B. Oertli 2011. Freshwater biodiversity under climate warming pressure: Identifying the winners and losers in temperate standing waterbodies. Biological Conservation 144: 2311-2319.

Rundle, S.D., A. Foggo, V. Choiseul \& D.T. Bilton 2002. Are distribution patterns linked to dispersal mechanism? An investigation using pond invertebrate assemblages. Freshwater Biology 47: 1571-1581.

Santamaría, L. 2002. Why are most aquatic plants widely distributed? Dispersal, clonal growth and smallscale heterogeneity in a stressful environment. Acta Oecologica 23: 137-154.

Thies, H., U. Nickus, V. Mair, R. Tessadri, D. Tait, B. Thaler \& R. Psenner 2007. Unexpected response of high alpine lake waters to climate warming. Environmental Science \& Technology 41: 7424-7429.

Vanschoenwinkel, B., A. Waterkeyn, T. Vandecaetsbeek, O. Pineau, P. Grillas \& L. Brendonck 2008. Dispersal of freshwater invertebrates by large terrestrial mammals: a case study with wild boar (Sus scrofa) in Mediterranean wetlands. Freshwater Biology 53: 2264 2273.

Waterkeyn, A., B. Vanschoenwinkel, S. Elsen, M. Anton-Pardo, P. Grillas \& L. Brendonck 2010. Unintentional dispersal of aquatic invertebrates via footwear and motor vehicles in a Mediterranean wetland area. Aquatic Conservation Marine and Freshwater Ecosystems 20: 580-587.

Wilson, K.A., M. Lulow, J. Burger, Y.-C. Fang, C. Andersen, D. Olson, M. O'Connell \& M.F. McBride 2011. Optimal restoration: accounting for space, time and uncertainty. Journal of Applied Ecology 48: 715-725.

Winterbourn, M.J., W.L. Chadderton, S.A. Entrekin, J.L. Tank \& J.S. Harding 2007. Distribution and dispersal of adult stream insects in a heterogeneous montane environment. Fundamental and Applied Limnology 168: 127-135. 


\section{Authors}

Beat Oertli ${ }^{1}$

is professor and coordinates the research institute Land-Nature-Environment. His activities focus on freshwater biodiversity: assessment methods, relation to environmental variables and impact of perturbations (e.g. nutrient enrichment, warming).

\section{Christiane Ilg}

is a research scientist. Her primary interest is freshwater biodiversity, with a special focus on the ecology of small waterbodies in relation to climate change or urbanization.

\section{Sandrine Angélibert ${ }^{1}$}

is a hydrobiologist and odonatologist. Her research activities focus on biodiversity of aquatic macroinvertebrates in ponds and lakes. She worked at the University of Applied Sciences Western Switzerland (LandNature-Environment institute) from 2006 to 2012.

\section{Janine Bolliger}

is a landscape ecologist at the Swiss Federal Research Institute WSL, Birmensdorf, and PD (lecturer) for Landscape Modelling at the Department of Environmental Sciences, ETH Zurich, Switzerland. Her research foci include landscape genetics and scenariobased modelling of land-use change.

\section{Julien Crovadore}

is a research scientist and phytopathology lecturer at hepia (Plants and Pathogens Group). His main research skills: plant cell culture, terpenes study, PCR diagnosis, biological control, bioinformatic (phylogeny, metagenomic, metatranscriptomics, genome assembling).

\section{Eliane Demierre}

is a lab technician. Her main topics are the ecology of aquatic macroinvertebrates, dragonflies and amphibians and their taxonomy. She is mainly involved in fieldwork and laboratory analysis.

\section{Claire Julliand}

worked at the University of Applied Sciences Western Switzerland (Land-Nature-Environment institute) as a research scientist until 2013. She specializes in sustainable use of natural resources.

\section{Andrea Finger-Stich ${ }^{1}$}

is a lecturer. Her research activities focus on sustainable use of natural resources. She conducted her doctoral research on the participation of local communities in forestry in the Swiss and French Alps. She is also working as an independent environmental advisor.

\section{Christel Forré}

is a senior research scientist in the Institute of Life Technologies. Her activities focus on the development and validation of PCR methods: typing, quantitation, identification of genes and organisms.

\section{Pierre-André Frossard}

is professor. His research activities focus on ecological restoration and environmental engineering, especially of streams, rivers, ponds and lakes.

\section{François Lefort ${ }^{1}$}

is a professor and heads the research group Plants and Pathogens, which focuses on molecular diagnostics of plant pathogens and development of biological control agents.

\section{Mathieu Mayencourt ${ }^{\top}$}

is a graduate (Bachelor in Nature Management). His bachelor thesis focused on the biodiversity inventory of boreo-alpine beetles and dragonflies of selected alpine ponds (Canton Valais, Switzerland).

\section{Umberto Piantini ${ }^{1}$}

is professor. His research interests include analytical chemistry and analysis of organic structures.

\section{Sergio Schmid}

is professor and heads the Institute of Life Technologies. During his academic and professional career he acquired expertise in the fields of qPCR method development and of recombinant peptide production.

${ }^{1}$ University of Applied Sciences Western Switzerland

Appendix 1 - The 41 cold stenotherm species occurring in Swiss wetlands from three groups: aquatic vascular plants, dragonflies and aquatic beetles (e.g. Rosset \& Oertli 2011). Statuses of species classified on the Swiss red list are indicated: EN = endangered, VU = vulnerable.

\begin{tabular}{|l|l|}
\hline Vascular plants & $\begin{array}{l}\text { Arabis subcoriacea, Cardamine amara, Carex frigida, Carex juncella (VU), Carex nigra, Carex norvegica (EN), Carex paupercula, } \\
\text { Cochlearia pyrenaica (VU), Dactylorhiza cruenta (VU), Epilobium alsinfolium, Epilobium nutans, Eriophorum angustifolium, } \\
\text { Eriophorum scheuchzeri, Isoëtes lacustris (VU), Juncus filiformis, Montia fontana (EN), Ranunculus reptans (EN), Rorippa islandica, } \\
\text { Saxifraga stellaris, Sparganium angustifolium and Vaccinium microcarpum (VU) }\end{array}$ \\
\hline Odonata & $\begin{array}{l}\text { Coenagrion hastulatum, Leucorrhinia dubia, Aeshna subartica (VU), Aeshna caerulea (VU), Somatochlora artica, Somatochlora } \\
\text { alpestris, Aeshna juncea }\end{array}$ \\
\hline Coleoptera & $\begin{array}{l}\text { Agabus laponicus, Agabus melanarius (EN), Hydroporus foveolatus, Hydroporus incognitus (EN), Hydroporus marginatus (VU), } \\
\text { Hydroporus melanarius, Hydroporus memnonius, Hydroporus nigellus (VU), Hydroporus nigrita, Hydroporus obscurus (VU), Hy- } \\
\text { droporus sabaudus (H. nivalis) (VU), llybius erichsoni and Stictotarsus griseostriatus }\end{array}$ \\
\hline
\end{tabular}

